\title{
Faktor Internal, Makroekonomi dan Pembiayaan Bermasalah Bank Syariah di Indonesia
}

\author{
Yudhistira Ardana \\ STMIK Pringsewu \\ ardanayudhistira@gmail.com
}

\begin{abstract}
Non Performing Financing is the most important issue for banks to survive. This study aims to analyze the determination of internal and external factors on Non Performing FInancing on Sharia Banking in Indonesia. This study uses Error Correction Model analysis techniques. The results show that in the short term the variables that have a significant effect on Non Performing Financing on Sharia Banking in Indonesia are inflation variables, while the Exchange Rate, Bank Indonesia Certificate of Wadi'ah, Industrial Production Index, Financing Deposite Ratio, and Capital Adequacy Ratio variables have no significant effect. In the long run the variables that are influential are Exchange Rate, Bank Indonesia Certificate of Wadi'ah, Financing Deposite Ratio, and Capital Adequacy Ratio, while Inflation and Industrial Production Index have no significant effect.
\end{abstract}

Keywords: non performing financing, internal and external factors, sharia banking

\begin{abstract}
Abstrak
Non Performing Financing adalah isu yang paling penting bagi bank untuk bertahan hidup. Penelitian ini bertujuan untuk menganalisis determinasi faktor internal dan eksternal terhadap pembiayaan bermasalah pada Perbankan Syariah di Indonesia. Penelitian ini menggunakan teknik analisis model koreksi kesalahan. Hasil penelitian menunjukkan bahwa dalam jangka pendek variabel yang berpengaruh signifikan terhadap pembiayaan bermasalah pada perbankan syariah di Indonesia yaitu variabel inflasi, sedangkan variabel kurs, Sertifikat Wadiah Bank Indonesia, Indeks Produksi Industri, Financing Deposite Ratio, dan Capital Adequacy Ratio tidak berpengaruh secara signifikan. Pada jangka panjang variabel yang berpengaruh yaitu Kurs, Sertifikat Wadiah Bank Indonesia, Financing Deposite Ratio dan Capital Adequacy Ratio, sedangkan Inflasi dan Indeks Produksi Industri tidak berpengaruh secara signifikan.
\end{abstract}

Kata kunci: pembiayaan bermasalah, faktor internal dan eksternal, perbankan syariah 


\section{PENDAHULUAN}

Perbankan merupakan sarana yang strategis dalam rangka pembangunan ekonomi, peran yang strategis tersebut terutama disebabkan oleh fungsi utama bank sebagai penghimpun dan penyalur dana dari masyarakat secara efektif dan efisien untuk mencapai tujuan pembangunan nasional (Mutamimah \& Chasanah, 2012). Di Indonesia, terdapat dua jenis bank umum yaitu bank konvensional dan bank syariah. Berbeda halnya dengan bank konvensional yang penyaluran dananya lebih banyak pada sektor keuangan yang berorientasi pada bisnis, penyaluran dana perbankan syariah diwujudkan dalam bentuk pembiayaan dengan prinsip bagi hasil dalam sektor riil yakni sektor yang memberikan output hasil produksi. Dana yang disalurkan perbankan syariah memiliki dampak cukup besar bagi perkembangan sektor riil sebab produk pembiayaan syariah dengan prinsip profit/loss sharing dan paradigma kemitraan dinilai sangat tepat bagi pengembangan usaha yang menghasilkan output produksi.

Data Statistik Perbankan Syariah yang diterbitkan oleh Otoritas Jasa Keuangan (OJK) menyebutkan bahwa saat ini terdapat Bank Umum Syariah (BUS) sebanyak 13 unit dan Unit Usaha Syariah (UUS) sebanyak 21 unit dari Bank Umum Konvensional yang tergabung dalam industri perbankan syariah di Indonesia. Dana Pihak Ketiga (DPK) tercatat selalu mengalami peningkatan terhitung pada bulan Desember 2018 sebesar Rp 371,83 triliun. Jumlah ini meningkat sebesar 11,03\% dibandingkan tahun 2017 dan 60,84\% dibandingkan 3 tahun sebelumnya pada tahun 2015. Sedangkan total dari berbagai jenis pembiayaan yang berhasil disalurkan oleh perbankan syariah mencapai Rp 321,31 triliun yang meningkat 12,02\% dibandingkan tahun 2017 dan 50,15\% dibandingkan 3 tahun terakhir. Dari sejumlah indikator tersebut di atas, BUS memiliki pangsa terbesar dari $69,28 \%$ dari total DPK dan $63,11 \%$ dari total pembiayaan industri perbankan syariah.

Bank Syariah pada awalnya dikembangkan sebagai suatu respon dari kelompok ekonomi dan praktisi perbankan muslim yang berupaya mengakomodasi desakan dari berbagai pihak yang menginginkan agar tersedia jasa transaksi keuangan yang dilaksanakan sejalan dengan nilai moral dan prinsip-prinsip Islam (Firdaus, 2015). Perkembangan perbankan syariah di Indonesia telah menjadi tolak ukur keberhasilan eksistensi ekonomi syariah. Krisis moneter yang terjadi pada tahun 1998 telah menenggelamkan bank-bank konvensional dan banyak bank konvensional yang dilikuidasi karena kegagalan sistem bunganya. Sementara perbankan yang menerapkan sistem syariah dapat tetap eksis dan mampu bertahan. Berbeda dengan perbankan konvensional, perbankan syariah menyediakan pembiayaan dalam bentuk barang nyata (asset) baik yang didasarkan pada konsep jual beli, sewa-menyewa, ataupun bagi hasil (Vanni \& Rokhman, 2017).

Dalam menjalankan fungsi-fungsinya, sebuah bank membutuhkan dana, oleh karena itu, setiap bank selalu berusaha untuk memperoleh dana yang optimal tetapi dengan cost of money yang wajar. Semakin banyak dana yang dimiliki suatu bank, semakin besar peluang bagi bank tersebut untuk melakukan kegiatan-kegiatannya dalam mencapai tujuannya (Ardana \& Irviani, 2017). Bank sebagai lembaga keuangan menghadapi risiko pembiayaan karena fungsi utamanya menyalurkan dana kepada masyarakat dalam bentuk kredit maupun pembiayaan. Kredit merupakan aset berisiko yang dimiliki oleh bank, agar tidak menderita kerugian bank harus menjaga dan mengamankannya (Maidalena, 2014). Dengan diberikannya kredit atau pembiayaan, maka bank memiliki risiko adanya pembiayaan atau kredit macet. 
Tingkat pembiayaan atau kredit bermasalah memengaruhi tingkat kepercayaan masyarakat terhadap bank sehingga akan berpengaruh pada perekonomian Indonesia. Non Performing Financing merupakan proksi yang digunakan dalam mencerminkan tingkat pembiayaan bermasalah dan risiko pembiayaan.

Tabel 1. Perkembangan Total Asset, Pembiayaan dan NPF pada BUS dan UUS

\begin{tabular}{ccccc}
\hline Keterangan & $\mathbf{2 0 1 5}$ & $\mathbf{2 0 1 6}$ & $\mathbf{2 0 1 7}$ & $\mathbf{2 0 1 8}$ \\
\hline Pembiayaan & 212.996 & 248.007 & 262.898 & 296.429 \\
NPF & 9.248 & 10.298 & 10.940 & 10.850 \\
Aset & 296.262 & 356.504 & 377.618 & 433.738 \\
\hline
\end{tabular}

Sumber: Laporan Tahunan OJK, data diolah

Pada tabel 1 dapat dijelaskan bahwa dari tahun 2015 hingga 2018 tingkat pembiayaan yang disalurkan Bank Umum Syariah dan Unit Usaha Syariah meningkat tiap tahunnya. Hal tersebut diimbangi dengan total asset Bank Umum Syariah dan Unit Usaha Syariah yang juga meningkat tiap tahunnya. Pembiayaan bermasalah ternyata terjadi fluktuasi dimana angka pada tabel 1 menunjukkan bahwa ada kecenderungan meningkat. Pada tahun 2015 pembiayaan bermasalah sebesar 9.248 milyar, kemudian pada tahun 2016 naik menjadi 10.298 milyar dan pada tahun 2017 juga mengalami kenaikkan menjadi 10.940 milyar. Pada tahun 2018 terjadi penurunan pembiayaan bermasalah pada Bank Umum Syariah dan Unit Usaha Syariah menjadi 10.850 milyar. Kejadian ini dapat menunjukkan bahwa adanya pengelolaan yang kurang tepat dalam penyaluran pembiayaan. Oleh karena itu, perlu untuk dilakukan penelitian mengenai kondisi tersebut.

Nilai Non Performing Financing menggambarkan ketidakmampuan nasabah pembiayaan dalam mengembalikan pembiayaan beserta imbalannya setelah jangka waktu yang telah ditetapkan pada awal akad atau kontrak. Non Performing Financing yang tinggi menunjukkan banyaknya pembiayaan bermasalah yang terjadi, hal ini dapat memengaruhi sumber permodalan bagi bank karena bank kehilangan kepercayaan dari nasabah savings atas dana yang diamanahkannya kepada bank sehingga dapat menurunkan fungsi bank sebagai lembaga intermediasi keuangan. Bank dengan Non Performing Financing yang tinggi mengindikasikan bahwa kesehatan bank yang bersangkutan rendah karena banyak pembiayaan bermasalah yang terjadi dan pihak bank tidak mampu mengelola risiko pembiayaan dengan baik (Aryani dkk, 2016).

Rasio pembiayaan bermasalah menjadi ukuran kritis dalam mengevaluasi kinerja bank, kegiatan ekonomi, dan stabilitas serta kesehatan keuangan nasional (Vatansever \& Hepsen, 2013). Kualitas pembiayaan sensitif terhadap siklus ekonomi (Janvisloo dkk, 2013). Hal ini seperti yang dituangkan dalam teori akselerator keuangan oleh (Bernanke dkk, 1998) bahwa guncangan ekonomi kecil memiliki pengaruh yang relatif besar pada kegiatan peminjaman dan meminjam. Risiko bisnis perbankan yang tinggi akibat gejolak ekonomi dapat menyebabkan terjadinya ketidakstabilan sistem keuangan. Ketidakstabilan sistem keuangan yang tercermin dari indikator makroekonomi dapat memengaruhi tingkat pertumbuhan ekonomi di suatu negara (Haghighi dkk, 2012). Ketidakstabilan keuangan juga dapat dipengaruhi oleh kebijakan 
dan regulasi terutama yang terkait dengan governance atau tata kelola perusahaan (Mohr \& Wagner, 2013).

Pengaruh yang ditimbulkan dari pembiayaan bermasalah dapat memberikan efek domino bagi perekonomian apabila tidak ditangani dengan baik. Faktor-faktor yang menyebabkan terjadinya kredit bermasalah dapat disebabkan oleh tiga unsur, yaitu pihak bank atau kreditur, pihak debitur, dan pihak diluar kreditur serta debitur (Popita, 2013). Faktor kreditur merupakan faktor yang disebabkan oleh kinerja bankatau faktor internal, faktor diluar keduanya merupakan faktor yang bersifat makroekonomi atau faktor eksternal. (Curak dkk, 2013) menjelaskan tentang pentingnya meneliti kredit bermasalah dari suatu perbankan dengan melihat faktor makroekonomi dan faktor spesifik perbankan.

Kondisi makroekonomi dan karakteristik bank memiliki pengaruh yang berbeda pada pembiayaan bermasalah tergantung jenis pembiayaan bermasalah dan perbedaan sensitivitas dari berbagai jenis pembiayaan bermasalah terhadap perkembangan makroekonomi dapat dikaitkan dengan efek diferensial dari siklus bisnis pada arus kas agen dan nilai aset yang dijaminkan (Louzis dkk, 2012). Risiko pembiayaan bermasalah dapat disebabkan dari sisi internal bank berupa kinerja bank itu sendiri dan sisi eksternal berupa kondisi makroekonomi (Auliani \& Syaichu, 2016).

Faktor eksternal penyebab kredit bermasalah salah satunya direpresentasikan dengan Kurs. Kurs pada suatu negara merupakan hal yang sangat penting dimana kurs dapat menentukan biaya dari produk suatu negara bagi pembeli luar negeri dan akan mempengaruhi ekspor dari negara tersebut, begitu juga dengan impor. Perkembangan nilai tukar sangat berpengaruh pada kegiatan ekonomi, dimana ketika semakin tingginya jumlah mata uang lokal (Rupiah) yang harus dikeluarkan untuk mendapatkan mata uang asing (Dollars), maka akan meningkatkan potensi semakin tingginya rasio Non Performing Financing. Disaat nilai mata uang dalam negeri terdepresiasi maka dapat menyebabkan capital out flow atau pelarian modal masyarakat keluar negeri karena jika dibandingkan dengan mata uang negara lain maka nilai tukar Rupiah terlalu rendah. Semakin meningkatnya nilai tukar Dollars akan menaikkan permintaan Dollars. Bagi para debitur bank besar yang kegiatan usahanya sangat membutuhkan kurs Dollars akan mengalami tekanan dengan terdepresiasinya nilai tukar sehingga akan meningkatkan risiko gagal bayar (default) atau kredit macet. Beberapa penelitian terkait antara variabel kurs dan Non Performing Financing adalah hasil penelitian (Auliani \& Syaichu, 2016; Mutamimah \& Chasanah, 2012; Purnamasari \& Sukmana, 2017), serta (Ardana \& Irviani, 2017) yang menunjukkan bahwa, variabel Kurs berpengaruh positif tetapi tidak signifikan terhadap Non Performing Financing. Sementara dalam penelitian (Firdaus, 2015) menunjukkan sebaliknya dimana variabel Kurs berpengaruh negatif tetapi tidak signifikan dan penelitian (Vanni \& Rokhman, 2017) mendapatkan hasil bahwa variabel kurs berpengaruh positif dan signifikan terhadap Non Performing Financing.

Penyebab lain yang mempengaruhi Non Performing Financing dari sisi ekternal bank dan debitur adalah Inflasi yang juga merupakan representasi kondisi makroekonomi. Inflasi merupakan momok bagi setiap negara, karena inflasi hampir dialami oleh setiap negara diberbagai belahan dunia. Tidak dapat dipungkiri bahwa kegiatan untuk menekakan laju inflasi merupakan salah satu bentuk kebijakan ekonomi yang sering dikenal dengan stabilitas harga. Pengaruh inflasi terhadap perbankan yaitu, pada saat inflasi mengalami kenaikkan 
pada level tinggi, maka harga barang akan mengalami peningkatan. Ketika harga meningkat, pengeluaran masyarakat akan lebih besar dibandingkan keadaan normal. Oleh karena itu, jumlah pengeluaran yang meningkat berbanding terbalik kepada kemampuan nasabah untuk membayar kewajibannya yang pada akhirnya berdampak pada peningkatan kredit macet. Beberapa penelitian seperti hasil penelitian oleh (Auliani \& Syaichu, 2016; Firdaus, 2015; Mutamimah \& Chasanah, 2012; Popita, 2013), serta (Ardana \& Irviani, 2017) menunjukkan variabel inflasi berpengaruh negatif tetapi tidak signifikan terhadap Non Performing Financing. Sedangkan dalam penelitian (Nasution \& Ulum, 2015; Purnamasari \& Musdholifah, 2016), serta (Vanni \& Rokhman, 2017), variabel inflasi berpengaruh positif tetapi tidak signifikan terhadap Non Performing Financing.

Sertifikat Wadiah Bank Indonesia (SWBI) juga merupakan representasi dari kondisi makroekonomi. SWBI merupakan surat berharga berdasarkan prinsip syariah berjangka waktu pendek dalam mata uang rupiah yang diterbitkan oleh Bank Indonesia. SWBI diterbitkan sebagai salah satu instrumen operasi pasar terbukadalam rangkapengendalian moneter yang dilakukan berdasarkan prinsip syariah denganmenggunakan akad ju'alah. Karena SWBI bagi Bank adalah sarana investasi dalam perbankan syariah yang diharapkan untuk memperoleh bonus atau return, sehingga Bank dapat menambah pendapatan untuk kemudian disalurkan kepada masyarakat melalui berbagai pembiayaan (Dahlan, 2014). Hasil penelitian (Auliani \& Syaichu, 2016), variabel SWBI berpengaruh positif dan signifikan terhadap Non Performing Financing. Sementara dalam penelitian (Poetry \& Sanrego, 2011), serta (Dahlan, 2014) variabel SWBI berpengaruh negatif tetapi tidak signifikan terhadap Non Performing Financing.

Representasi kondisi makroekonomi yang lain yaitu IPI (Industrial Production Index). Sektor industri menjadi penggerak utama pembangunan ekonomi nasional. Hal ini dikarenakan telah mampu memberikan kontribusi signifkan dalam peningkatan nilai tambah, lapangan kerja dan devisa, serta mampu memberikan kontribusi yang besar dalam pembentukan daya saing nasional. Penelitian (Nasution \& Ulum, 2015; Nuryartono dkk, 2016; Poetry \& Sanrego, 2011), serta (Ramadhan, 2017) menyatakan bahwa variabel IPI (Industrial Production Index) berpengaruh positif signifikan terhadap Non Performing Financing. Penelitian Budiman dkk (2018) menghasilkan penelitian yang berbeda dimana variabel IPI (Industrial Production Index) berpengaruh negatif dan signifikan terhadap Non Performing Financing.

Selain faktor eksternal juga terdapat faktor internal perbankan yaitu Financing Deposite Ratio (FDR) yang dalam ini menjadi salah satu penyebab tejadinya pembiayaan yang bermasalah pada bank syariah. Financing to Deposit Ratio (FDR) merupakan rasio perbandingan antara pembiayaan dan dana pihak ketiga (DPK). Semakin tinggi rasio FDR maka akan semakin berisiko buat bank, namun semakin rendah rasio FDR mengindikasikan bahwa fungsi intermediasi pada bank tidak berjalan dengan baik. Hasil penelitian yang dilakukan oleh (Aryani dkk, 2016; Nasution \& Ulum, 2015) serta (Ramadhan, 2017) memperoleh hasil bahwa variabel Financing Deposite Ratio berpengaruh secara positif dan signifikan terhadap Non Performing Financing. Sedangkan (Popita, 2013) mendapatkan hasil bahwa variabel Financing Deposite Ratio berpengaruh positif tetapi tidak signifikan. Hasil berbeda diperoleh dari penelitian (Akbar, 2016; Poetry \& Sanrego, 2011) serta (Vanni \& Rokhman, 2017), yang mendapatkan hasil bahwa variabel FDR berpengaruh negatif dan signifikan terhadap Non Performing Financing. 
Faktor internal lainnya yaitu Capital Adequacy Ratio (CAR). Capital Adequacy Ratio (CAR) adalah rasio yang digunakan untuk mengukur kecukupan modal yang dimiliki bank untuk menunjang aktiva yang mengandung risiko, seperti halnya terhadap kredit/pembiayaan yang diberikan. Besarnya CAR dapat mempengaruhi kemampuan bank dalam mengambil keputusan terkait risiko. Hasil penelitian (Poetry \& Sanrego, 2011), dan (Ramadhan, 2017) menunjukkan bahwa variabel Capital Adequacy Ratio berpengaruh positif dan signifikan terhadap Non Performing Financing. Hasil penelitian berbeda diperoleh oleh (Akbar, 2016; Aryani dkk, 2016; Budiman dkk, 2018), serta (Auliani \& Syaichu, 2016) yang menunjukkan bahwa variabel Capital Adequacy Ratio berpengaruh negatif dan signifikan terhadap Non Performing Financing. Berdasarkan tingkat fluktuasi Non Performing Financing yang cukup tinggi serta adanya gap dari hasil penelitian sebelumnya misalnya seperti, hanya menggunakan varibel internal atau eksternal saja, selain itu sebagian besar penelitian terdahulu hanya mengukur jangka panjang saja tidak dengan jangka pendeknya, untuk itu peneliti ingin meneliti lebih lanjut mengenai faktor internal, makroekonomi pada pembiayaan bermasalah bank syariah di Indonesia dengan menggunakan Error Correction Model (ECM) dimana pada penelitian ini akan diukur dampak yang ditimbulkan pada jangka pendek dan jangka panjang.

\section{METODE}

Jenis data yang digunakan pada penelitian ini seluruhnya merupakan data sekunder yang penulis peroleh melalui situs resmi setiap instansi yang bersangkutan yaitu Bank Indonesia (www.bi.go.id), Otoritas Jasa Keuangan (www.ojk.go.id) dan Badan Pusat statistik (www.bps.go.id). Data yang digunakan merupakan data time series bulanan pada bulan Januari 2011 hingga Desember 2018. Variabel internal perbankan dalam penelitian ini di proksikan dengan Financing Deposite Ratio (FDR) dan Capital Adequacy Ratio (CAR), sedangkan variabel eksternal dari makroekonomi di proksikan dengan Kurs, Inflasi, SWBI/ SBIS dan IPI (Industrial Production Index). Tujuan dari penelitian ini yaitu untuk mengetahui pengaruh faktor internal perbankan dan makroekonomi terhadap Non Performing Financing (NPF) pada bank syariah di Indonesia.

Penelitian ini menggunakan teknik analisis data yaitu Metode Koreksi Kesalahan (Error Correction Model). Metode Error Correction Model digunakan karena Error Correction Model mempunyai kemampuan untuk menganalisis fenomena ekonomi jangka pendek dan jangka panjang serta mengkaji konsisten atau tidaknya model empirik dengan teori ekonomi. Selain itu penggunaan metode ECM dalam penelitian ini didasarkan pada data penelitian yang berbentuk time series yang seringkali tidak stasioner sehingga menyebabkan hasil regresi yang meragukan atau disebut juga dengan regresi lancing (Widarjono, 2013a). Regresi lancung adalah situasi dimana hasil regresi menunjukkan koefisien regresi yang signifikan secara model tidak saling berhubungan. Error Correction Model (ECM) merupakan model yang tepat bagi data time series yang tidak stasioner tersebut. Data yang tidak stasioner seringkali menunjukkan hubungan ketidakseimbangan dalam jangka pendek, tetapi ada kecenderungan terjadinya hubungan keseimbangan dalam jangka panjang (Widarjono, 2013b). Model ECM memiliki ciri khas dengan masuknya unsur Error Corection Term (ECT) dalam model. Error Corection Term (ECT) digunakan sebagai ukuran jangka pendek untuk keseimbangan jangka panjang dan apabila koefisien ECT signifikan secara statistik, maka 
model yang digunakan dalam penelitian adalah valid. Berikut ini model estimasi jangka panjang yang penulis gunakan:

Ln_NPF $=\beta_{0}+\beta_{1}$ Ln_Kurs $+\beta_{2}$ Inflasi $\beta_{3} \operatorname{Ln} \_$SWBI $+\beta_{4} \operatorname{Ln} \_$IPI $+\beta_{5} \operatorname{Ln} \_$FDR $+\beta_{6} \operatorname{Ln} \_$CAR $+e_{t}$

Sedangkan model estimasi jangka pendek yang penulis gunakan adalah:

$$
\begin{aligned}
\Delta \mathrm{Ln}_{-} \mathrm{NPF}= & \beta_{0}+\beta_{1} \Delta \mathrm{Ln}_{-} \mathrm{Kurs}_{\mathrm{t}-1}+\beta_{2} \Delta \operatorname{Inflasi}_{\mathrm{t}-1} \beta_{3} \Delta \mathrm{Ln}_{-} \mathrm{SWBI}_{\mathrm{t}-1}+\beta_{4} \Delta \mathrm{Ln}_{-} \mathrm{IPI}_{\mathrm{t}-1}+\beta_{5} \Delta \mathrm{Ln}_{-} \mathrm{FDR}_{\mathrm{t}-1} \\
& +\beta_{6} \Delta \mathrm{Ln}_{-} \mathrm{CAR} \mathrm{t}_{\mathrm{t}-1}+\mathrm{ECT}
\end{aligned}
$$

Untuk mengetahui apakah model ECM ini tepat atau tidak digunakan dalam estimasi model regresi, bisa dilakukan dengan melihat t-statistik dari variabel koreksi kesalahan (ECT atau Resid-1) hasil regresi ECM. Apabila nilai t-statistik ECT atau Resid-1 lebih besar dari 2 maka model ECM tepat digunakan dalam estimasi model regresi, sebaliknya apabila tidak melebihi 2 maka model ECM tidak tepat digunakan dalam estimasi model regresi (Widarjono, 2013).

\section{HASIL DAN PEMBAHASAN}

Pada tahap pertama akan dilakukan uji akar-akar unit guna mengetahui pada derajat keberapa data yang digunakan stasioner. Pengujian ini dilakukan untuk mengetahui apakah koefisien tertentu adalah satu atau (mempunyai akar unit). Dalam observasi ini, pengujian akar unit Menggunakan Augmented Dickey Fuller (ADF). Untuk melihat stasioner atau tidaknya suatu data time series dapat dilakukan dengan membandingkan statistik dengan Mac Kinnon Critical Value pada $\alpha=1 \%$; 5\% dan 10\%. Jika pada tingkat level data yang diujikan belum stasioner, maka akan dilanjutkan dengan uji derajat integrasi pada tingkat first difference. Berikut tabel hasil uji akar unit pada tingkat level.

Tabel 2 Hasil Uji Akar Unit

\begin{tabular}{ccccc}
\hline \multirow{2}{*}{ Variabel } & \multicolumn{2}{c}{ Nilai ADF } & \multicolumn{2}{c}{ Nilai Kritis MacKinnon 5\% } \\
& Level & 1st Difference & Level & 1st Difference \\
\hline Inflasi & -8.862103 & - & -3.501445 & - \\
Kurs & -1.184533 & -7.556752 & -3.500669 & -3.501445 \\
IPI & -1.404328 & -9.929557 & -3.502238 & -3.502238 \\
SWBI & -1.625562 & -8.181781 & -3.500669 & -3.501445 \\
FDR & -1.372859 & -11.01163 & -3.500669 & -3.501445 \\
NPF & -1.299045 & -4.716188 & -3.503049 & -3.503049 \\
CAR & -6.068497 & - & -3.500669 & - \\
\hline
\end{tabular}

Tabel 2 menunjukkan bahwa variabel-variabel yang digunakan dalam penelitian tidak seluruhnya stasioner pada tingkat level. Hanya variabel inflasi dan CAR yang stasioner pada tingkat level, sedangkan variabel kurs, IPI, SWBI, FDR dan NPF tidak. Ketidakstasioneran data dapat dilihat dari nilai t-ADF yang lebih besar dari nilai kritis MacKinnon pada taraf 5\%. Oleh karena itu, pengujian akar-akar unit perlu dilanjutkan pada tingkat first difference. Setelah dilakukan first difference, barulah semua data stasioner pada taraf nyata 5\%, artinya data yang digunakan dalam penelitian ini terintegrasi pada ordo satu I (1). 
Table 3 Uji Kointegrasi

\begin{tabular}{ccccc}
\hline $\begin{array}{c}\text { Hypothesized } \\
\text { No. of CE(s) }\end{array}$ & Eigenvalue & $\begin{array}{c}\text { Trace } \\
\text { Statistic }\end{array}$ & $\begin{array}{c}\mathbf{0 . 0 5} \\
\text { Critical Value }\end{array}$ & Prob.** $^{* *}$ \\
\hline None * & 0.601413 & 206.5048 & 125.6154 & 0.0000 \\
At most 1 * & 0.402670 & 120.9608 & 95.75366 & 0.0003 \\
At most 2 * & 0.263741 & 73.03918 & 69.81889 & 0.0270 \\
At most 3 & 0.188804 & 44.56504 & 47.85613 & 0.0986 \\
At most 4 & 0.137190 & 25.10516 & 29.79707 & 0.1577 \\
At most 5 & 0.080369 & 11.38202 & 15.49471 & 0.1891 \\
At most 6 & 0.037869 & 3.590196 & 3.841466 & 0.0581 \\
\hline
\end{tabular}

Pada tahap uji kointegrasi ini, dapat mengetahui adanya hubungan jangka panjang antar variabel. Jika terdapat kointegrasi maka data tersebut memiliki analisis jangka panjang antar variabel, jika tidak terdapat kointegrasi maka dapat dikatakan tidak memiliki jangka panjang dan tidak perlu dicari jangka panjangnya. Melihat adanya kointegrasi antar variabel dapat dilihat dengan cara membandingkan nilai kritis dengan nilai trace statistiknya. Jika nilai kritis $(\alpha=1 \%, 5 \%, 10 \%)<$ nilai trace statistiknya maka dapat diambil kesimpulan bahwa terdapat kointegrasi antar variabel. Jika nilai kritis > nilai trace statistiknya maka tidak terdapat kointegrasi. Berdasarkan hasil olah data pada tabel 3 di atas dengan menggunakan eviews, menunjukan bahwa terdapat kointegrasi pada nilai critical value 5\%, yang artinya jika terdapat kointegrasi, maka data tersebut bisa dianalisis jangka panjangnya. Model selanjutnya adalah pengujian regresi jangka panjang dan regresi jangka pendek.

Tabel 4 Hasil Estimasi ECM Jangka Panjang

\begin{tabular}{ccccc}
\hline Variable & Coefficient & Std. Error & t-Statistic & Prob. \\
\hline C & 7.859145 & 2.112587 & 3.720152 & 0.0003 \\
CAR & -0.142117 & 0.051400 & -2.764925 & 0.0069 \\
FDR & -0.074404 & 0.012225 & -6.086437 & 0.0000 \\
INFLASI & -0.068296 & 0.097169 & -0.702855 & 0.4840 \\
IPI & 0.005610 & 0.012015 & 0.466962 & 0.6417 \\
KURS & 0.000191 & $8.46 E-05$ & 2.264699 & 0.0260 \\
SWBI & 0.408920 & 0.070119 & 5.831776 & 0.0000 \\
Rdjusted R-squared & 0.815684 & F-statistic & & 0.000000 \\
\hline
\end{tabular}

Berdasarkan hasil regresi yang telah dilakukan, diketahui bahwa nilai probabilitas (F-statistik) atau uji F sebesar 0,000000. Dapat disimpulkan bahwa nilai F statistik berada dibawah nilai alpha $=5 \%$ dan secara statistik dapat dikatakan signifikan. Hal ini menunjukan bahwa variabel internal (FDR dan CAR) dan eksternal (inflasi, kurs, IPI dan SWBI) secara simultan berpengaruh terhadap pembiayaan bermasalah (NPF) dalam jangka panjang. 
Berdasarkan dari hasil Estimasi Persamaan Jangka Panjang pada Tabel 4, dapat diketahui bahwa nilai koefisien determinasi yang disesuaikan (Adjusted $R$ Square) sebesar 0,803258, artinya bahwa kemampuan variabel independen dalam menjelaskan perubahan nilai variabel dependen adalah sebesar 80,32\% dan sisanya sebesar 19,68\% dipengaruhi oleh faktor-faktor lain di luar model. Untuk uji signifikansi parameter secara keseluruhan diketahui bahwa F-statistic sebesar 65,64441 dengan probabilitas F Statistic sebesar 0,000000 $<\alpha$ (level of significance) 1\%. Hal ini menunjukkan bahwa secara bersama-sama perubahan semua variabel independen dalam model mempunyai pengaruh yang signifikan terhadap perubahan nilai variabel dependen. Dengan demikian, secara simultan terdapat pengaruh faktor internal (FDR, dan CAR) dan faktor makroekonomi (Kurs, SWBI, Inflasi, dan IPI) terhadap NPF dinyatakan diterima.

Untuk menyatakan apakah model ECM yang digunakan sahih atau tidak maka koefisien Error Corection Term (ECT) harus signifikan. Jika koefisien ini tidak signifikan maka model tersebut tidak cocok dan perlu dilakukan perubahan spesifikasi lebih lanjut. Nilai ECT digunakan untuk mencari perbedaan koefisien jangka pendek dan jangka panjang. Oleh karena itu nilai ini sering disebut disequilibrium error. Berikut disajikan tabel hasil perhitungan uji ECT.

Tabel 5. Hasil Uji ECT

\begin{tabular}{lccc}
\hline & & t-Statistic & Prob.* $^{*}$ \\
\hline Augmented Dickey-Fuller test statistic & -4.227219 & 0.0010 \\
Test critical values: & $1 \%$ level & -3.500669 & \\
& $5 \%$ level & -2.892200 & \\
& $10 \%$ level & -2.583192 & \\
\hline
\end{tabular}

*MacKinnon (1996) one-sided p-values.

Tabel 5 memperlihatkan bahwa nilai ECT-nya stasioner pada level sehingga dapat dikatakan terjadi kointegrasi. Selanjutnya untuk melihat model jangka pendeknya dapat meregresikan semua variabel pada difference dengan data error lag $1\left(\mathrm{e}_{\mathrm{t}-1}\right)$. Pada tabel 5 dapat dilihat bahwa probabilitas Error Correction Term (ECT) sebesar 0,0010 yang berarti signifikan karena lebih kecil dari 5\%. Artinya model Error Correction Model yang digunakan dalam penelitian ini tepat. Dapat disimpulkan juga bahwa keseluruhan variabel independen dalam penelitian ini mempengaruhi variabel dependen, selain itu memberikan efek jangka panjang dan jangka pendek terhadap variabel dependen.

Koefisien determinasi $\left(R^{2}\right)$ digunakan untuk mengukur seberapa besar variasi variabel independen mampu menjelaskan variasi variabel dependenya. Apabila nilai $R^{2}$ semakin mendekati 1, maka semakin baik garis regresi mampu menjelaskan data aktualnya, semakin mendekati 0 maka semakin kurang baik. Pada tabel 6 dapat dijelaskan bahwa nilai koefisien determinasi hasil regeresi jangka pendek adalah sebesar 0,187046 atau 18.70\%. Artinya dalam jangka pendek pembiayaan bermasalah (NPF) dapat dijelaskan oleh variasi variabel independen yaitu faktor internal (FDR, dan CAR) dan faktor makroekonomi (Kurs, SWBI, Inflasi, dan IPI) sebesar $18.70 \%$, sedangkan sisanya $81.30 \%$ dijelaskan oleh faktor atau variabel lain di luar model. 
Tabel 6 Hasil Estimasi ECM Jangka Pendek

\begin{tabular}{ccccc}
\hline Variable & Coefficient & Std. Error & t-Statistic & Prob. \\
\hline C & 0.013073 & 0.031620 & 0.413448 & 0.6803 \\
D(CAR) & -0.037716 & 0.031826 & -1.185084 & 0.2392 \\
D(FDR) & 0.006447 & 0.015682 & 0.411128 & 0.6820 \\
D(INFLASI) & -0.148849 & 0.051027 & -2.917053 & 0.0045 \\
D(IPI) & 0.005276 & 0.008973 & 0.587935 & 0.5581 \\
D(KURS) & $-2.93 E-05$ & 0.000154 & -0.190040 & 0.8497 \\
D(SWBI) & 0.052504 & 0.112110 & 0.468323 & 0.6407 \\
E(-1) & -0.255091 & 0.066897 & -3.813197 & 0.0003 \\
R-squared & 0.247585 & F-statistic & & 4.089677 \\
Adjusted R-squared & 0.187046 & Prob(F-statistic) & & 0.000635 \\
\hline
\end{tabular}

Berdasarkan analisis data yang telah dilakukan dapat diketahui bahwa variabel kurs pada jangka pendek berpengaruh negatif signifikan terhadap variabel NPF. Hal ini diperoleh dari nilai probabilitas 0,8497 dan nilai koefisien sebesar -2,93 yang artinya jika terjadi kenaikkan kurs sebesar 1\% maka akan menurunkan NPF sebesar 2,93 pada periode jangka pendek, begitu juga sebaliknya. Sedangkan dalam jangka panjang variabel kurs berpengaruh positif dan signifikan terhadap variabel NPF. Hal ini diperoleh dari nilai probabilitas sebesar 0,0260 dan nilai koefisien sebesar 0,000191 yang artinya jika terjadi kenaikkan kurs sebesar 1\%, maka akan menaikkan NPF sebesar 0,000191 pada periode jangka panjang, begitu juga sebaliknya. Perubahan dari nilai kurs rentan terhadap kredit yang bermasalah dan jatuhnya nilai tukar dikarenakan adanya kepanikan pada kalangan pelaku pasar. Hubungan antara kredit bermasalah dan nilai tukar dapat berdampak pada aktivitas ekonomi khususnya produsen yang menggunakan bahan baku impor, sehingga dengan terdepresiasinya nilai tukar maka harga bahan baku impor naik dan hal tersebut membebani biaya produksi, pada akhirnya hal tersebut akan berdampak pada profit dan pendapatan produsen.

Maka produsen sebagai debitur akan terpengaruh terhadap pembayaran pinjaman pada bank. Jika kurs tinggi, nilai rupiah juga tinggi sehingga semakin banyak nilai rupiah yang dikeluarkan masyarakat dan mengurangi upaya mereka dalam melunasi hutangnya. Karena adanya kurs atau nilai tukar rupiah terhadap dollar yang tinggi akan mengakibatkan nilai rupiah menurun dalam arti semakin banyak rupiah yang akan dikeluarkan untuk suatu transaksi, hal tersebut akan berdampak secara langsung terhadap masyarakat. Bagi mereka yang telah mempunyai angsuran pembiayaan pada bank syariah, akan cenderung tidak memenuhi kewajibannya. Hasil penelitian ini didukung oleh (Vanni \& Rokhman, 2017), yang menyatakan bahwa variabel kurs berpengaruh positif dan signifikan terhadap NPF.

Inflasi pada periode jangka pendek memiliki pengaruh negatif dan signifikan yang dalam hal ini dapat dibuktikan dengan nilai probabilitasnya sebesar 0,0045 dan nilai koefisien sebesar $-0,148849$. Hal tersebut dapat direpresentasikan bahwa setiap kenaikkan inflasi sebesar $1 \%$ maka akan berdampak pada penurunan NPF sebesar 0,148849 pada periode jangka pendek, begitu juga sebaliknya. Sedangkan dalam jangka panjang inflasi berpengaruh negatif tetapi tidak signifikan terhadap NPF, hal ini dapat dibuktikan dengan nilai probabilitasnya sebesar 
0.4840 dan nilai koefisien sebesar -0,068296. Hal tersebut dapat direpresentasikan bahwa setiap kenaikkan inflasi sebesar 1\% maka akan berdampak pada penurunan NPF sebesar 0,068296 pada periode jangka panjang, begitu juga sebaliknya. Hasil penelitian ini didukung oleh teori bahwa kenaikan tingkat inflasi akan menaikan harga barang-barang yang ada di masyarakat. Fenomena ini dapat memberikan dampak positif bagi pihak penjual karena dapat meningkatkan hasil pendapatan yang akan diperoleh dengan asumsi total biaya yang dikeluarkan lebih rendah dari total penerimaan. Oleh karena itu, kemampuan pihak penjual sebagai nasabah bank syariah dalam mengembalikan pembiayaan yang disalurkan oleh bank syariah akan meningkat sehingga dapat menurunkan tingkat NPF bank syariah di Indonesia. Dalam kaitannya inflasi dengan NPF akan membawa dampak buruk pada pertumbuhan kondisi keuangan perusahaan dan rumah tangga. Melambungnya harga membuat daya beli masyarakat akan berkurang dan pendapatan yang diterima dari penjualan produk dan jasa akan semakin menurun. Perusahaan dan rumah tangga yang modalnya di dapat dari pembiayaan perbankan akan mengalami masalah dalam pengembalian kepada pihak bank. Hal ini akan menyebabkan rasio atau tingkat NPF semakin tinggi bagi perbankan sendiri. Begitu juga sebaliknya. Di sisi lain, seperti yang dikatakan Poetry dan Sanrego (2011), ketika inflasi terjadi, nilai bagi hasil SBIS menurun yang menyebabkan perbankan syariah menurunkan tingkat imbal hasil pembiayaannya, sehingga permintaan pembiayaan meningkat. Pembiayaan untuk konsumsi dengan marjin rendah akan meningkatkan daya beli nasabah perbankan syariah, sehingga barang dan jasa dapat terserap dalam perekonomian dan penjualan meningkat. Hal ini memberikan kemudahan bagi nasabah perbankan syariah dalam mengembalikan pembiayaannya, sehingga NPF pada perbankan syariah menurun. Kesimpulannya adalah peningkatan inflasi tidak selalu diikuti peningkatan NPF perbankan syariah. Hasil penelitian ini didukung oleh (Auliani \& Syaichu, 2016; Firdaus, 2015; Mutamimah \& Chasanah, 2012), serta (Ardana \& Irviani, 2017) yang menyatakan bahwa variabel inflasi berpengaruh negatif tetapi tidak signifikan terhadap NPF.

IPI (Industrial Production Index) dalam periode jangka pendek memiliki pengaruh negatif tetapi tidak signifikan yang dalam hal ini dapat dibuktikan dengan nilai probabilitasnya sebesar 0,5581 dan nilai koefisien sebesar 0,005276. Hal tersebut dapat direpresentasikan bahwa setiap IPI mengalami kenaikkan sebesar 1\% maka akan berdampak pada kenaikkan NPF sebesar 0,005276 pada periode jangka pendek, begitu juga sebaliknya. Sedangkan dalam jangka panjang IPI berpengaruh positif tetapi tidak signifikan terhadap NPF, hal ini dapat dibuktikan dengan nilai probabilitasnya sebesar 0,6417 dan nilai koefisien sebesar 0,005610. Hal tersebut dapat direpresentasikan bahwa setiap IPI mengalami kenaikkan sebesar 1\% maka akan berdampak pada kenaikkan NPF sebesar 0,005610 pada periode jangka panjang, begitu juga sebaliknya. Ketika pertumbuhan ekonomi membaik yang direfleksikan dengan peningkatan pertumbuhan indeks produksi industri, mendorong sektor usaha dan rumah tangga untuk melaksanakan aktivitas perekonomiannya dengan baik. Pelaku usaha akan menganggap pertumbuhan ekonomi sebagai insentif untuk meningkatkan produksinya, sementara masyarakat mengalami peningkatan daya beli akibat kenaikan pendapatan. Pelaku usaha akan memperoleh kenaikan keuntungan dari pembelian masyarakat, sehingga dapat melunasi pembiayaannya. Di sisi lain, masyarakat yang mengalami kenaikan pendapatan rumah tangga akan lebih mudah mengembalikan utang pembiayaannya. Oleh karena itu, 
terjadi peningkatan kapasitas pengembalian pembiayaan oleh pelaku usaha dan rumah tangga yang akan menurunkan pembiayaan bermasalah (NPF). Ketika IPI naik, maka penjualan dan pendapatan produsen meningkat dan perolehan pendapatan ini digunakan untuk target pertambahan produksi ditahun berikutnya yang berdampak pada pertambahan tenaga kerja dan pertumbuhan ekonomi. Hal ini mengindikasikan bahwa ketika terjadi booming, perbankan syariah lebih optimis terhadap kondisi perekonomian masyarakat sehingga perbankan syariah akan meningkatkan penyaluran pembiayaannya dengan harapan mendapatkan return yang besar. Namun, yang terjadi hal ini menyebabkan perbankan syariah menjadi lebih longgar dalam ketentuan penyaluran pembiayaannya sehingga nasabah yang seharusnya tidak layak mendapatkan pembiayaan menjadi bisa mendapatkan pembiayaannya dan hal ini bisa diperburuk dengan adanya oknum-oknum tidak bertanggung jawab dengan memanfaatkan optimisme perbankan terhadap peningkatan IPI untuk tujuan yang tidak baik. Kondisi ini tentu akan meningkatkan risiko perbankan dan pada akhirnya meningkatkan NPF pada perbankan syariah. Hasil penelitian ini sesuai dengan (Nasution \& Ulum, 2015; Nuryartono dkk, 2016; Poetry \& Sanrego, 2011), serta (Ramadhan, 2017) yang menyatakan bahwa variabel IPI (Industrial Production Index) berpengaruh positif.

Sertifikat Wadiah Bank Indonesia (SWBI) dalam periode jangka pendek memiliki pengaruh positif tetapi tidak signifikan yang dalam hal ini dapat dibuktikan dengan nilai probabilitasnya sebesar 0,6407 dan nilai koefisien sebesar 0,052504. Hal tersebut dapat direpresentasikan bahwa setiap SWBI mengalami kenaikkan sebesar 1\% maka akan berdampak pada kenaikkan NPF sebesar 0,052504 pada periode jangka pendek, begitu juga sebaliknya. Sedangkan dalam jangka panjang SWBI berpengaruh positif dan signifikan terhadap NPF, hal ini dapat dibuktikan dengan nilai probabilitasnya sebesar 0,0000 dan nilai koefisien sebesar 0,408920. Hal tersebut dapat direpresentasikan bahwa setiap SWBI mengalami kenaikkan sebesar 1\% maka akan berdampak pada kenaikkan NPF sebesar 0,408920 pada periode jangka panjang, begitu juga sebaliknya. Penempatan dana pada SBIS mengakibatkan jumlah uang yang beredar di masyarakat menjadi sedikit karena dana yang disalurkan kembali kepada nasabah menjadi berkurang. Dengan berkurangnya jumlah uang yang beredar ini membuat nasabah menjadi kesulitan untuk mengembalikan dana yang mereka dapatkan melalui pembiayaan yang diberikan oleh bank syariah. Penggunaan SWBI selain menjadi piranti untuk pengendalian uang beredar juga dijadikan sarana penitipan jangka pendek khususnya bagi bank yang mengalami kelebihan likuiditas. Pada saat tertentu, SWBI menarik bagi perbankan syariah untuk menanamkan dananya pada instrumen ini dibandingkan disalurkan melalui pembiayaan karena adanya berbagai faktor, diantaranya faktor resiko. Apabila semakin tinggi tingkat bonus SWBI, akan mengurangi pembiayaan bermasalah bank syariah (NPF). Meningkatnya SWBI menyebabkan peningkatan pada suku bunga kredit bank sehingga mengakibatkan keinginan masyarakat dalam meminjam dana akan berkurang (Putra \& Rustriyuni, 2015). Hasil penelitian ini didukung oleh (Auliani \& Syaichu, 2016), dimana variabel SWBI berpengaruh positif dan signifikan terhadap NPF.

Financing Deposite Ratio (FDR) dalam periode jangka pendek memiliki pengaruh positif tetapi tidak signifikan yang dalam hal ini dapat dibuktikan dengan nilai probabilitasnya sebesar 0,6820 dan nilai koefisien sebesar 0,006447. Hal tersebut dapat direpresentasikan bahwa setiap FDR mengalami kenaikkan sebesar 1\% maka akan berdampak pada kenaikkan NPF 
sebesar 0,006447 pada periode jangka pendek, begitu juga sebaliknya. Sedangkan dalam jangka panjang FDR berpengaruh negatif dan signifikan terhadap NPF, hal ini dapat dibuktikan dengan nilai probabilitasnya sebesar 0,0000 dan nilai koefisien sebesar 0,408920. Hal tersebut dapat direpresentasikan bahwa setiap FDR mengalami kenaikkan sebesar 1\% maka akan berdampak pada kenaikkan NPF sebesar 0,408920 pada periode jangka panjang, begitu juga sebaliknya. Financing Deposito Ratio (FDR) merupakan variabel yang memberika kontribusi yang besar terhadap Non Performing Financing (NPF) perbankan syariah. Hal ini dikarenakan Financing Deposito Ratio (FDR) perbankan syariah sangatlah tinggi, bahkan bisa mencapai lebih dari $100 \%$. Tingkat Financing Deposito Ratio (FDR) yang sangat tinggi tersebut tentu akan memberikan kontribusi yang besar terhadap tingkat Non Performing Financing (NPF) perbankan syariah. Ketika Financing Deposito Ratio (FDR) yang tinggi tidak didukung dengan loan review dan pengawasan yang baik, maka akan menjadi bumerang bagi perbankan syariah yang diakibatkan oleh naiknya tingkat Non Performing Financing (NPF) perbankan syariah akibat meningkatnya pembiayaan yang bermasalah atau macet (Akbar, 2016). Penelitian tersebut juga menyatakan bahwa variabel yang memiliki kontribusi besar terhadap tingkat NPF bank syariah adalah kondisi internal perbankan syariah, yaitu tingkat FDR. Jika alasan pembiayaan bermasalah lebih disebabkan oleh faktor teknis, besarnya alokasi pinjaman harusnya akan menambah jumlah kredit bermasalah. Artinya faktor penyebab kredit bermasalah tidak semata aspek teknis tetapi variabel yang lebih kompleks melibatkan keperilakuan dan aspek makro yaitu inflasi, suku bunga, dan sebagainya (Faiz, 2010). Hasil penelitian ini didukung oleh (Aryani dkk, 2016; Nasution \& Ulum, 2015) serta Ramadhan (2017), yang mendapatkan hasil bahwa variabel FDR berpengaruh positif dan signifikan terhadap NPF.

Capital Adequacy Ratio (CAR) dalam periode jangka pendek memiliki pengaruh negatif tetapi tidak signifikan yang dalam hal ini dapat dibuktikan dengan nilai probabilitasnya sebesar 0,2392 dan nilai koefisien sebesar -0,037716. Hal tersebut dapat direpresentasikan bahwa setiap CAR mengalami kenaikkan sebesar 1\% maka akan berdampak pada penurunan NPF sebesar 0,037716 pada periode jangka pendek, begitu juga sebaliknya. Sedangkan dalam jangka panjang CAR berpengaruh negatif dan signifikan terhadap NPF, hal ini dapat dibuktikan dengan nilai probabilitasnya sebesar 0,0069 dan nilai koefisien sebesar -0,142117. Hal tersebut dapat direpresentasikan bahwa setiap CAR mengalami kenaikkan sebesar 1\% maka akan berdampak pada penurunan NPF sebesar 0,142117 pada periode jangka panjang, begitu juga sebaliknya. (Akbar, 2016) menyatakan bahwa semakin tinggi rasio kecukupan modal maka akan dapat berfungsi untuk menampung risiko kerugian yang dihadapi oleh bank karena peningkatan pembiayaan bermasalah. Jadi, kecukupan modal merupakan faktor yang sangat penting bagi bank dalam rangka menampung risiko kerugian terutama risiko kerugian atas tidak dibayarkannya. Hal tersebut menunjukkan bahwa semakin tinggi CAR maka semakin besar jumlah modal yang digunakan untuk menampung risiko kerugian gagal bayar. Dengan demikian CAR merupakan faktor penting dalam mitigasi risiko yang dilakukan perbankan terkait kemungkinan gagal bayar debitur dalam membayar pinjamannya (Aryani dkk, 2016). Dampak dari peningkatan pembiayaan macet dapat mengakibatkan penurunan pendapatan BUS dan berakibat pada turunnya tingkat bagi hasil kepada nasabah pemilik dana. Lebih jauh, akumulasi jumlah pembiayaan macet yang relatif besar dapat mengurangi modal bank secara cepat dan meningkatkan potensi bank menjadi gagal beroperasi. Hasil 
penelitian ini didukung oleh (Akbar, 2016; Aryani dkk, 2016; Auliani \& Syaichu, 2016) yang menunjukkan bahwa variabel CAR berpengaruh negatif dan signifikan terhadap NPF.

\section{SIMPULAN}

Penelitian ini bertujuan untuk menguji pengaruh jangka pendek dan jangka panjang faktor internal dan eksternal terhadap pembiayaan bermasalah pada perbankan syariah di Indonesia. Hasil penelitian menunjukkan bahwa dalam jangka pendek variabel yang berpengaruh signifikan terhadap pembiayaan bermasalah pada perbankan syariah di Indonesia yaitu variabel inflasi, sedangkan variabel kurs, SWBI, IPI, FDR dan CAR tidak berpengaruh signifikan. Pada jangka panjang variabel yang berpengaruh yaitu Kurs, SWBI, FDR dan CAR, sedangkan inflasi dan IPI tidak berpengaruh signifikan. Penelitian ini memberikan rekomendasi bahwa penting bagi industri perbankan syariah hendaknya mempertimbangkan faktor makro seperti kurs, inflasi, SWBI dan IPI dalam kebijakan pembiayaannya, untuk menghindari peningkatan pembiayaan yang bermasalah. Di saat kurs rupiah terhadap dollar meningkat atau di saat Indeks industri nasional meningkat maka perlu ada kehati-hatian dalam penyaluran pembiayaan ini dikarenakan Industri Nasional Kita Masih mengandalkan bahan baku impor untuk menjalankan bisnisnya, begitu juga pada saat SWBI mengalami penurunan maka perlu ada kebijakan agar tidak terjadi peningkatkan pembiayaan bermasalah. Perbankan Syariah juga perlu memperhatikan faktor mikro seperti CAR dan FDR dalam pembiayaannya. Pembiayaan dapat ditingkatkan jika perusahaan dirasa memiliki kecukupan modal yang baik yaitu mendekati angka $8 \%$ dan sehingga kemampuan modal bank dapat dikatakan baik.

Adanya kebijakan regulator untuk membentuk tambahan modal berupa capital conservation buffer, countercyclical buffer dan capital surcharge merupakan langkah kebijakan yang layak dijadikan perhatian. Ke depan kebijakan tersebut dapat menjadi salah satu alat regulator dalam mengarahkan perbankan nasional melalui variasi penentuan besaran komponen variabel-variabel kebijakan tersebut. Peneliti selanjutnya diharapkan dapat mengembangkan model penelitian dengan range data yang lebih panjang dan penggunaan variabel yang lebih variatif sehingga dapat menangkap determinan lainnya yang dapat mempengaruhi NPF.

\section{PUSTAKA ACUAN}

Akbar, D. (2016). Inflasi, Gross Domesctic Product (GDP), Capital Adequacy Ratio (CAR), Dan Finance To Deposit Ratio (FDR) Terhadap Non Performing Financing (NPF) Pada Bank Umum Syariah Di Indonesia. Jurnal I-Economic, 2(2), 19-37.

Ardana, Y \& Irviani, R. (2017). Kondisi Makroekonomi Terhadap Tingkat Pembiayaan Bermasalah Bank Umum Syariah di Indonesia (Periode Januari 2009-Desember 2015 dengan model ECM). Media Trend, 12(1), 1-11.

Aryani, Y., Anggraeni, L., \& WIliasih, R. (2016). Faktor-Faktor yang Memengaruhi Non Performing Financing pada Bank Umum Syariah Indonesia Periode 2010-2014. Jurnal AL-Muzara'ah, 4(1), 44-60.

Auliani, M. M. \& Syaichu, M. (2016). Analisis Pengaruh Faktor Internal Dan Faktor Eksternal Terhadap Tingkat Pembiayaan Bermasalah Pada Bank Umum Syariah Di Indonesia Periode Tahun 2010-2014. Diponegoro Journal of Management, 5(3), 1-14. 
Bernanke, B., Gertler, M., \& Gilchrist, S. (1998). The Financial Accelerator in A Quantitative Business Cycle Framework (No. 6455).

Budiman, R., Achsani, N. A., \& Ismal, R. (2018). Risiko Pembiayaan dan Determinannya pada Pebankan Syariah di Indonesia. Jurnal Aplikasi Manajemen Dan Bisnis, 4(1), 151-159.

Curak, M., Pepur, S \& Poposki, K. (2013). “ Determinants of non-performing loans - evidence from Southeastern European banking systems " Determinants of non-performing loans - evidence from Southeastern European banking systems. Banks and Bank Systems, $8(1), 45-53$.

Dahlan, R. (2014). Pengaruh Tingkat Bonus Sertifikat Bank Indonesia Syariah Dan Tingkat Inflasi Terhadap Pembiayaan Bank Syariah Di Indonesia. ETIKONOMI, 13(2), 104-117.

Faiz, I. A. (2010). . Ketahanan Kredit Perbankan Syariah Terhadap Krisis Keuangan Global. Jurnal Ekonomi Islam. Ekonomi Islam, 4(2).

Firdaus, R. N. (2015). Pengaruh Faktor Internal Dan Eksternal Yang Mempempengaruhi Pembiayaan Bermasalah Pada Bank Umum Syariah Di Indonesia. El-DInar, 3(1), 82-108.

Haghighi, H. K., Sameti, M., \& Ishfani, R. D. (2012). The Effect of Macroeconomic Instability on Economic Growth in Iran. Research in Applied Economics, 4(3), 39-61.

Janvisloo, M. A., Muhammad, J., \& Hassan, T. (2013). Macroeconomics Shocks and Stability in Malaysian Banking System; A Structural VAR Model. American Journal of Economics, $3(5), 22-28$.

Louzis, D. P., Vouldis, A. T., \& Metaxas, V. L. (2012). Macroeconomic and Bank-Specific Determinants of Non-Performing Loans in Greece: A Comparative Study of Mortgage, Business, and Consumer Loan Portofolios. Journal of Banking and Finance, 36, 1012-1027.

Maidalena. (2014). Analisis Faktor Non Performing Financing ( NPF ) padaIndustri Perbankan Syariah. Jurnal Ekonomi Dan Bisnis Islam, 1(1), 127-138.

Mohr. B., \& Wagner, H. (2013). A Structural Approach to Financial Stability: on the Beneficial Role of Regulatatory Governance. Journal of Governance and Regulation, 2(1), 7-26.

Mutamimah \& Chasanah, S. N. Z. (2012). Analisis Eksternal Dan Internal Dalam Menentukan Non Performing Financing Bank Umum Syariah Di Indonesia. Jurnal Bisnis Dan Ekonomi (JBE), 19(1), 49-64.

Nasution, Z., \& Ulum, A. S. (2015). Analisis Risiko Pembiayaan Syariah Pada Sektor Ekonomi. Jurnal Kompilek, 7(2), 110-122.

Nuryartono, N., Saptono, I. T., \& Was'an, G. A. (2016). Kaitan Kondisi Makroekonomi Dengan Non Performing Financing Berdasarkan Sektor Ekonomi Pada Perbankan Syariah Di Indonesia. Jurnal Keuangan Dan Perbankan., 20(1), 104-115.

Poetry, Z. D. \& Sanrego, Y. D. (2011). Pengaruh Variabel Makro Dan Mikro Terhadap NPL Perbankan Konvensional Dan NPF Perbankan Syariah. Islamic Fianance \& Business Review Journal, 6(2), 79-104.

Popita, M. S. A. (2013). Analisis Penyebab Terjadinya Non Performing Financing Pada Bank Umum Syariah Di Indonesia. Accounting Analysis Journal, 2(4), 404-412. 
Purnamasari, A. E. \& Musdholifah, M. (2016). Analisis Faktor Eksternal Dan Internal Bank Terhadap Risiko Pembiayaan Bank Umum Syariah Di Indonesia Periode 2012-2015. Jurnal BISMA, 9(1), 13-25.

Purnamasari, D. \& Sukmana, R. (2017). Pengaruh Harga Emas Dunia, Harga Minyak Mentah Dunia Dan Indeks Produksi Industri Terhadap Indeks Saham Di Jakarta Islamic Index (JII) dalam Jangka Panjang Dan Jangka Pendek (Periode Januari 2005-Desember 2015). Jurnal Ekonomi Syariah Teori Dan Terapan, 4(7), 515-530.

Putra, G. O. P., \& Rustriyuni, S. D. (2015). Pengaruh DPK, BI Rate, dan NPL terhadap Penyaluran Kredit Modal Kerja Pada BPR Di Provinsi Bali tahun 2009-2014. Jurnal EP Unud, 4(5), 451-464.

Ramadhan, P. (2017). Determinan Pembiayaan Bermasalah Sektor Pertambangan Pada Perbankan Syariah. Jurnal Akuntabilitas, 10(2), 368-390.

Vanni, K. M. \& Rokhman, W. (2017). Analisis Faktor-Faktor Yang Mempengaruhi Non Performing Financing Pada Perbankan Syariah Di Indonesia Tahun 2011-2016. Jurnal EQUILIBRIUM, 5(2), 306-319.

Vatansever, M., \& Hepsen, A. (2013). Determining Impacts on Non-Performing Loan Ratio in Turkey. Journal of Finance and Investment Analysis, 2(4), 119-129.

Widarjono, A. (2013a). Ekonometrika Teori dan Aplikasi. Yogyakarta: UPP STIM YKPN.

Widarjono, A. (2013b). Ekonometrika Teori dan Aplikasi. Yogyakarta: UPP STIM YKPN. 